\title{
Sparks, Garry G.: Rewriting Maya Religion. Domingo de Vico, K'iche' Maya intellectuals, and the Theologia Indorum
}

\author{
Louisville, CO: University Press of Colorado, 2019, ISBN: 978- \\ 1607329695, 434 p.
}

\section{Iris Gareis ${ }^{1}$}

Published online: 4 November 2020

(C) The Author(s) 2020

With the present volume, Garry G. Sparks, Associate Professor and Director of Undergraduate Programs at George Mason University's Religious Studies Department, adds another important contribution to our knowledge of the encounter between Iberian Catholicism and Maya religion during the first decades of contact. As in former publications (e.g. 2017), his interest is centred upon the interrelation and dialogue between Catholic missionaries and Highland Maya intellectuals at an early stage of Spanish colonial rule in the Mesoamerican realm. Sparks' special concern with the work of Domingo de Vico is motivated by the fact that his Theologia Indorum bears testimony to the mutual influence mendicant missionaries and local indigenous population exerted on each other. Vico's text, written in a Highland Mayan language (presumably K'iche') as well as various writings authored by Maya intellectuals, is linked through an underlying dialogue on religious concepts and ideas. Although Vico's Theologia Indorum was not published, nor translated into any European language and only survived fragmented and in contemporaneous translations into other Highland Mayan languages, it nevertheless played a very important role in the production and transmission of knowledge on Catholic and Mayan religions, introducing Christian thought to Maya groups of the Guatemalan highlands and at the same time absorbing Maya ways of religious and cultural thinking. It is precisely this specific historic situation during the first post-contact period in the Guatemalan highlands, approximately from the 1520 s to the $1580 \mathrm{~s}$, of intense cultural communication and interreligious dialogue between missionaries of mendicant orders and local indigenous people that Garry Sparks brings into focus.

Vico completed the first volume in February of 1553 and the second volume of his magnum opus in November 1554 (102), making it the first explicit Christian theology

Iris Gareis

i.gareis@em.uni-frankfurt.de

1 Goethe-University, Frankfurt am Main, Germany 
to be written in the Americas $(4,13)$. Still more important, the Theologia Indorum sheds light on various features concerning the translation of Christian terms into indigenous languages and their conceptualisation. In a similar way as present-day ethnographers draw upon the help of members of the society they study, many of the mendicant authors writing in indigenous languages were assisted by native speakers. Thus, as a matter of fact, many of these texts were written by more than one author. In the case of Vico, his main consultant on the language and culture of the K'iche' was probably Diego Reynoso, a member of the pre-Hispanic K'iche' ruling council and author of several important Maya notarial documents (100). Vico's Theologia Indorum shows that he was very well-informed of Highland Maya Theogony and cosmogony as well as of high register poetry of Maya moral and ritual discourse $(23,173)$. At the same time, many of the Maya texts, written by indigenous authors, as, for example, those composed or co-authored by Diego Reynoso, display features that point to a close relationship with Vico's Theologia Indorum. In this context, Sparks mentions explicitly two other K'iche'an documents, both dating from the 1550s and authored or at least coauthored by Diego Reynoso (173). The most important of these two writings is the Popol Wuj, written between 1554 and 1558 and co-authored by Reynoso. Similar to what had happened with Vico's text, the Popol Wuj remained unnoticed, until around the year 1701 when Dominican father Francisco Jiménez transcribed the K'iche' version and prepared a Spanish translation of the Book of the Counsel. Subsequently, he included parts of the Spanish translation in his history of the Dominican order in Chiapas and Guatemala. Karl Ritter von Scherzer (1856), an Austrian diplomat and natural scientist, retrieved Jiménez' Spanish translation from the archive of the Academia de la Ciencia de Guatemala and published it in 1856. Translations into French, German, and English (Edmonson 1971; Tedlock 1985) followed. In the 2000s, the Popol Wuj became one of the most popular texts on Mayan mythology and history. Unlike the localised audience of fellow K'iche' Maya when it was written, at present, it reaches readers all over the globe. The second important K'iche' text associated with the authorship of Diego Reynoso is the Title of Totonicapán (Carmack \& Mondloch, 1983). Written in 1554, the text was first known in a Spanish translation made in 1834 by the priest Dionisio José Chonay at the request of the inhabitants of Totonicapán to support their land claims. Finally, in 1973, Robert M. Carmack was shown a box with at least seven manuscripts in K'iche', all land deeds (titulos), including the Title of Totonicapán (Morselli Barbieri 2004: 70-71).

While the Popol Wuj and the Title of Totonicapán were clearly influenced by Vico's Theologia Indorum, their authors did not simply copy or adopt concepts from the Dominican's writing but rather used it in subtler ways in incorporating or countering Vico's text. As Sparks puts it in the third part of his study, in which he traces Vico in K'iche' religious texts, the use of the Theologia Indorum in the Popol Wuj may be seen as a Maya response (197). It is, however, an indirect response to Vico, since the Popol Wuj always refers to his work only implicitly. In contrast, the Title of Totonicapán and various other notarial texts explicitly mention the Theologia Indorum or Vico. Sparks' detailed analysis of the different Highland Mayan texts and comparison with the Theologia Indorum highlights the fact that a mere transmission history as it has been written for a long time especially by mendicant missionaries and later their ecclesiastic successors cannot comprehend the underlying complex processes of intercultural and interreligious communication (229-331). 
Very little is known on the author of the Theologia Indorum, the Dominican friar Domingo de Vico. He was born between 1485 and 1519 in southern Spain and studied first in the Dominican convent of Úbeda and then at the University of Salamanca. After graduation, he returned to Úbeda. In 1544, he embarked with a large group of mendicant missionaries to the Americas, where he was to join the newly appointed bishop of Ciudad Real de Chiapa, the famous Bartolomé de las Casas. He reached his destination in 1545 and immediately began to work in the Dominican Maya region. At the same time, he was introduced to K'iche' language by fellow Dominican Luis de Cáncer, who wrote that Vico was a natural talent, learning quickly and mastering an indigenous language in some weeks. From 1551 to 1554, he was prior of the Dominican convent of Guatemala. During this time, he probably worked with Diego Reynoso, one of the authors of the Popol Wuj. In addition to his Theologia Indorum completed in $1553 / 1554$, he composed several other treatises and religious texts in various Mayan languages. On November 30, 1555, he was shot in the attempt to pacify the rebellious Maya group of Ch'ol (95-103). Even less biographical data can be found of Diego Reynoso. As in Spain, also in Mexico, many documents perished over time or were destroyed in periods of political unrest. As a consequence, Sparks was confronted with the task to bring the dispersed fragments of the Theologia Indorum from archives and libraries together to reconstruct Vico's text as best as possible. In addition to a wide range of approaches and methods, such as "upstreaming" and "downstreaming", in order to gain a better understanding of the meaning of the historical concepts, Sparks stresses the importance of being well-informed on the religious foundation of both groups of actors in the encounter. The first part of Sparks' book is thus concerned with the pre-contact Maya and with the mendicants and their ideas and how they were shaping their respective "New World".

Part two, dedicated to recover Vico's K'iche'an theology, in a first step seeks to establish the writings attributed to Domingo de Vico. Table 3.1 (108-112) lists all the texts kept in different archives or libraries and those mentioned by other authors. As Sparks remarks, Vico's writings were highly appreciated by both Maya and mendicants. It seems that his works had an audience for several centuries following his death. The continuous use of the documents by mendicants visiting villages in the highlands and the readers among the Maya who would have liked to keep the texts in their place may account at least in part for the fragmentation and deterioration of manuscripts. In order to establish Vico's authorship, Sparks submits the documents attributed to the Theologia Indorum to a thorough analysis. In the following, Sparks proceeds in studying each chapter of Vico's work focusing especially on the concepts and their translation into K'iche'an Maya.

Particularly interesting is the example of the Spanish notions "good" (utz) and "evil" (itz). The term "good" presents no difficulties, neither in the Theologia Indorum nor in the contemporaneous Maya writings or in modern K'iche', whereas "evil" is only rarely used. The opposite of "good" is "not good" (man utz taj, na utz taj, or utz taj) or a variety of euphemisms, such as "dirty" ( $t z$ ' $i l)$. Sparks draws a line to other pairs of terms, also related to the discourse on morality (160). An almost identical treatment of the terms "good" and "evil" can be found in early vocabularies and other texts in the Andean languages Quechua and Aymara. As all Andean languages were lacking the term "evil", the early European missionaries contrasted the Quechua notion for "good" (alli) with "not good" (mana alli). It is however doubtful if this newly coined 
expression could be understood by Quechua-speakers, since "alli" rather conveys the meaning "good" in a material sense of "useful", or in a social sense of "good, useful for the society", but it had no moral implications (Crickmay 2008). This means that the idea of the early missionaries to express the concept of "evil" with "not good" led to confusion. Eventually, reinterpretations and reinventions of the concept of "evil" and consequently of the figure of the devil took place in many Latin American religions (Gareis 2008). It is interesting to note that according to the research of Garry Sparks, the construction "good" and "not good" in the realm of Highland Maya was not as problematic as in the Andes.

Sparks' detailed study and thorough analysis of a considerable corpus of texts written in K'iche' Mayan language highlight several features of the encounter and interactions between Spanish missionaries and Highland Mayan elites. He shows that the resulting intercultural and interreligious communication created a "New World" for Domingo de Vico as well as for the Mayan authors. In writing their texts informed by the culturally other, in reflecting the religious concepts and religious philosophy, and in using methods and techniques of the other, the European and the indigenous American authors brought a New World into being. This "New World" is built at the same time on Catholic European and Highland Maya traditions. Sparks also emphasises that their religious cultures overlapped but were never identical as the K'iche'an authors conceptualised their own theology.

Overall, Sparks' well-written book offers an immense amount of information on Hispanic Catholic and Highland Mayan religious thought, ritual, and cultural practices as well as new insights in the production and communication of knowledge. Furthermore, the author addresses a wide range of related topics, such as the problems of translation and conceptualisation or processes of religious and cultural change over time. Sparks states that the influence exerted by Vico's Theologia Indorum during several centuries on mendicant priests and the Mayan highland population was lost during the nineteenth century but suggests it would be inspiring for Catholic inculturation theology and "Indian" or "Mayan" theology. All this makes Rewriting Maya Religion a truly fascinating reading, opening a window into a remote past that brings the actors, mendicant missionaries and K'iche' Mayan authors, almost back to life.

\section{Acknowledgements Open Access funding enabled and organized by Projekt DEAL.}

Open Access This article is licensed under a Creative Commons Attribution 4.0 International License, which permits use, sharing, adaptation, distribution and reproduction in any medium or format, as long as you give appropriate credit to the original author(s) and the source, provide a link to the Creative Commons licence, and indicate if changes were made. The images or other third party material in this article are included in the article's Creative Commons licence, unless indicated otherwise in a credit line to the material. If material is not included in the article's Creative Commons licence and your intended use is not permitted by statutory regulation or exceeds the permitted use, you will need to obtain permission directly from the copyright holder. To view a copy of this licence, visit http://creativecommons.org/licenses/by/4.0/.

\section{References}

Carmack RM, Mondloch JL (1983) El título de Totonicapán: Texto, traducción y comentario. Universidad Nacional Autónoma de México, México 
Crickmay L (2008) Outward change, inner continuity: the Andean concept of "devil”. In: Gareis I (ed) Entidades maléficas y conceptos del mal en las religiones latinoamericanas. Evil Entities and Concepts of Evil in Latin American Religions. (BAS 45). Shaker Verlag, Aachen, pp 24-40

Edmonson MS (ed.) (1971) The book of the counsel: the Popol Vuh of the quiche Maya of Guatemala, publication 35, Tulane University, Middle American Research Institute, New Orleans

Gareis I (2008) El mal y sus representaciones en las religiones latinoamericanas / Introducción. Evil and its representations in Latin American religions / introduction. In: Gareis I (ed) Entidades maléficas y conceptos del mal en las religiones latinoamericanas. Evil Entities and Concepts of Evil in Latin American Religions. (BAS 45). Shaker Verlag, Aachen, pp 1-23

Morselli Barbieri S (2004) El Título de Totonicapán: consideraciones y comentarios. Estudios Mesoamericanos 6:70-85

Sparks G (2017) The Americas' first theologies: early sources of post-contact indigenous religion. Ed. and trans. By G. Sparks. With Frauke Sachse and Sergio Romero, Oxford University press Oxford; New York Tedlock D (transl) (1985) Popol Vuh: the Maya book of the dawn of life. Simon \& Schuster, New York von Scherzer KR (1856) Las Historias del origen de los Indios de Guatemala, por el R. P. F. Francisco Ximenes. Exactamente segun el texto español, del manuscrito original ... publicado per la primera vez y aumentado con una introducción y anotaciones por el Dr. C. Scherzer, Gerold, Wien

Publisher's Note Springer Nature remains neutral with regard to jurisdictional claims in published maps and institutional affiliations. 